\title{
SECOND SASKATCHEWAN RECORD OF THE RUFF
}

by J. F. Roy, Saskatoon

On May 8, 1965, Frank Brazier, Regina, sighted and later collected the first Ruff recorded in Saskatchewan (Brazier, 1965). This Eurasian shorebird, whose movements are the subject of considerable speculation, occurs fairly regularly in Eastern North America in both spring and fall. In 1963, for instance, there were 30 reports of this species in Audubon Field Notes (Peakall, 1965). The bird is a rarity west of the Mississippi, Frank Brazier's record being the first in ornithological literature (if one discounts occasional Siberian birds noted on the Alaska coast). To the west its nearest known breeding range is Northern Siberia, east to Lena, Kolyma (Rivers) and the New Siberian Islands (Novosibirskije), and on the east, Western France. It migrates throughout Europe and Asia, the regular western limits of its migration being N.W. England, France, Spain, Portugal and West Africa, while in the east is occurs regularly in Japan, China and Borneo. It is accidental in Iceland, and on the Bering and Pribi. lof Islands (Jourdain).

On May 19, 1970, Dr. Ron Bremner, Mark Abley and I were making one of our regular noon hour visits to the sloughs immediately north of the Saskatoon airport. While scanning the south shore of the slough nearly a quarter of a mile distant, I spotted what appeared to be a dark pigeon wading in the shallow water. This unusual behaviour made us wonder just what kind of bird we were looking: at. Moving closer, we realized that the "pigeon" was a handsome shorebird with a black mantle, a dark brown, mottled back, and a strong black line extending down the rump and the centre of its tail. Prominent white patches on either side of the tail and brilliant orange legs marked it as a species completely foreign to all of us. The bird was tame, allowing approach within 30 yards, as it walked casually in and out of the water and swam occasionally in the manner of a phalarope. After watching it closely for ten minutes we returned to the city to phone Dr. Bernard Gollop, Canadian Wildlife Service, and Dr. Stuart Houston. Mark Abley was able to lead them, in the company of Mary and Stanley Houston, back to the spot where the bird was still feeding. Dr. Houston confirmed our tentative identification. It was the second Ruff for Saskatchewan and a new addition to the Saskatoon bird list. Positive identification, by the way, was made only after consulting Lekagul's Bird Guide of Thailand!

We discovered later that Bill Richards had first spotted the Ruff (almost certainly the same bird) at the slough on May 9. He saw it there again on May 16. Uncertain of its identity and unaware of its rarity, he had described the bird carefully in his field notes, calling it a "confusing spring wader." While he had watched it, it had not displayed the large erectile ruff which we were fortunate enough to observe. This species, frequently found in the company of Yellowlegs, was alone while we studied it. Following an unsuccessful attempt to collect it, the Ruff was not seen again.

\section{LITERATURE CITED}

Brazier, Frank. 1965. First Saskatchewan record of the Ruff. Blue Jay, $23: 120-21$.

Lekagul, Boonsong. 1969. Bird guide of Thailand, printed with the advice of The Association for the Conservation of Wildlife, Bangkok.

Peakall, David. 1965. The status of the Ruff in North America. Wilson Bulletin, 77 : 294-96.

Witherby, Jourdain, Ticehurst and Tucker [n.d.] The handbook of British birds. H. F. and $G$. Witherby, London. 